\title{
ON SOME ACARINA FROM NORTH CAROLINA ${ }^{1}$
}

\author{
By Nathan Banks \\ Holliston, Mass.
}

Among a considerable number of mites collected by Prof. A. S. Pearse at Durham, North Carolina, are some new species and other rare or little known forms. Of particular interest is the rediscovery of Say's Erythrous mamillatus, which proves to belong to the genus Labidistomma, not previously recognized in the eastern part of our country. The genus Xenillus, hitherto not noted from America is also of interest; it was described many years ago as a new genus of beetles. The highly specialized group of Gymnodamæini is represented by four species, in three genera, two of which are new. A specimen of the peculiar Zetorchestes equestris, described by Berlese from Missouri, is the first in an American collection.

\section{ERYTHR AID 现 \\ Erythræus exilipes sp. nov. \\ Figs. 30, 35}

Body nearly two and one-fourth times as long as broad, broadest just above third coxæ, a little before middle of length, front margin nearly straight across, two eyes each side, about diameter apart, median groove about one-half as long as front margin. Body covered with stout, sharppointed spines, rather long, and mostly erect; many, when magnified, are seen to be covered with minute sharp spicules. Legs also with bristles, those on coxæ about as coarse as on body, but beyond becoming finer, and mostly appressed, those on the under side of the last joint of front legs very fine and short.

Legs long and slender, all tarsi swollen. Front legs nearly twice as long as body, the third joint from tip (tibia) about as long as greatest width of body, tarsus about two-thirds of protarsus; second pair of legs but little longer than body; the tarsus about three-fourths of

1 Published with a grant from the Museum of Comparative Zoölogy at Harvard College. 
protarsus; third legs plainly longer than second pair, tarsus about two-thirds of the slender protarsus; fourth legs fully two and one-half times as long as body, and very slender, the femora and tibia about equal in length, and each longer than width of body, the protarsus still longer, the tarsus not one-half of protarsus.

Palpi of moderate length, the third joint swollen, the sides convex, the fifth with stout, apical claw, the lower edge showing about five small, short teeth; the thumb strongly clavate, reaching beyond claw, and with many stiff bristles.

Length of body $1.8 \mathrm{~mm}$.

One from litter in Duke Forest, Durham, N. Car., 7 July (Pearse). Several young ones, of possibly the same species, taken at same place in July and August; these have very tenuous long leg's.

The length of the legs, and proportions of the joints thereof will separate the species from allied forms with such long hind legs. Type M.C.Z. Arachn. 3022.

\section{Erythræus carolinus sp. nov.} Figs. 1, 11

Body reddish, legs pale; body fully two-thirds as broad as long, broadly rounded; above with many erect, stiff, simple bristles, as broad at tip as at base, each about twice as long as the width of a femur.

Palpi not one-half the length of front tibia; all legs long and very slender, tarsi enlarged; front femora as as broad as body at third coxæ, the second pair a little longer than body, first pair more than twice the length of body; femur two about one-half of femur one; last joint of front legs considerably enlarged, broadest before tip, more than one-third the length of front tibia. Last joint of second and third legs not as much enlarged. Some of the hairs on legs are bristly on one edge. First and second pairs of legs well separated from the third and fourth.

Front margin of body concave, the corners over the base of front legs projecting slightly, and with three circular pits, and from each a hair, one short and somewhat clavate. 
Length $1.4 \mathrm{~mm}$.

One from Duke Univ. Forest, Durham, N. Car., 23 Sept., 1944 (Pearse). Type M.C.Z. Arachn. 3023.

\section{ORIBATID $\nexists$ \\ Oribatella carolina sp. nov. Figs. 2, 8}

Pale yellowish, edges of the lamella, edges of the square at base of cephalothorax, and the edges sloping back from each side dark brown; legs pale, almost hyaline. The cephalothorax is nearly as broad at base as long, the line of separation from abdomen crosses just above the square, a fainter line crosses the square. The square is partly open in front to a slender triangle which separates the bases of the broad lamellæ, which, beyond this triangle, appear united into one and extend to near tip of the cephalothorax, where there are two points near each other and each tipped by a short spine, the outer edge of each lamella is dark, at first slightly, evenly outcurved until halfway to the tip of cephalothorax and here the dark margin separates and projects forward in a slender, very sharp spine. Each side, a little lower down, is a lateral plate or lamella, nearly hyaline, about two-thirds the length of cephalothorax, and with a nipple-like tip, this may be the lateral part of the principal lamella, and the dark ridge, ending in a long spine, may be a ridge across the lamella.

Each side of this lower lamella is seen the edge of the tectopedium, this is very long. The submedian bristles are thick, slightly roughened, very long, with a slender pointed tip, and arise from just in front of the clear triangle which separates the lamellæ at base; the superior bristle is a very fine and extremely long hair, arising just in front of each anterior corner of the square; the seta is long, curves forward much as in O. plummeri, is thickened only near end which is roughened.

The abdomen is plainly longer than broad, the sides but little curved; the wing does not extend in front of the abdomen, is not very broad, and behind merges gradually into the outline of abdomen. On the venter the genital 
opening is mostly in front of hind trochanter, bilobed behind, almost as long as broad and fully twice its length in front of the smaller, nearly circular anal opening, which is nearly its length in front of the hind margin of venter.

The legs are very slender and short, with few hairs except on the tarsi.

Length .22 $\mathrm{mm}$.

From the Duke Forest, Durham, North Carolina, 2 Dec. (Pearse). Type M.C.Z. Arachn. 3021.

Alloribates gen. nov.

Goes in the Ceratozetinæ, related to Ceratozetes and Peloribates but differs in the structure of the front tarsi. The anterior border of the abdomen bulges forward over the hind part of the cephalothorax so that the origin of the setæ is plainly behind it. On each side of cephalothorax is a lamella reaching from near base of seta almost to the tip of head, it is rather close to the side margin all the way along, but at tip turns inward. Its highest part is toward the base. The wings are about as in Ceratozetes, the ventral openings are far apart, the setæ are quite long; legs of moderate length to short, the front pair extending in front of head, the femora and tibiæ are rather broad, but not strongly swollen. In the front legs the tibia extends over base of tarsus and ends in a long bristle, the tarsus is not quite as long as the tibia, its tip broadly truncate, and with one claw; on the upper side before tip of tarsus there is a cusp bearing a stout, curved bristle.

\section{Alloribates singularis sp. nov.}

Figs. 24, 25

Dull yellowish brown, legs paler. Abdomen nearly twice as long as broad, the sides in middle nearly parallel. Cephalothorax very short in middle, near each side margin is the long lamella, no visible hair at tip; setæ hardly as long as their distance apart, the tip fusiform, moderately swollen, and slightly scabrous; just in front of 
the suture are the two short, superior bristles, not far apart.

No hairs on abdomen; wings several times longer than broad, their lower edge (seen from below) rolled toward body. Genital opening small, twice its length in front of the much larger anal opening.

Legs short and fairly stout, upper side of second coxal bar reaching the genital opening, other bars shorter, and hind border of hind coxæ scarcely noticeable. Femora and tibiæ stout, but sides little rounded, tarsi tapering, except in front leg where it is broadly truncate, with a cusp on its upper side, bearing a curved stout bristle.

Length of body .36 to $.42 \mathrm{~mm}$.

Several specimens from Duke Forest, Durham, N. Car., numbers 475, 385, 238, 514, and March-April. Type M.C.Z. Arachn. 3020.

Minunthozetes angusta sp. nov.

Fig's. 37, 38

This is a more narrow species than the European type of the genus. The cephalothorax is about one-half as long as the abdomen; the lamella is a low, even, ridge arising close to the base of the seta and sloping forward to its fellow, not far behind the tip of head, the two lamellæ connected by a short translamella, similar to the lamella; apparently there is no hair at tip of lamella, nor noticeable superior bristles; on each side near side-margin is a short straight ridge, the lateral lamella. The seta is short, not reaching laterally beyond the legs, the basal two thirds slender and curved back, the apical third swollen, fusiform, and almost pointed at tip.

The abdomen is nearly one and one-half times as long as broad, for some distance the sides nearly parallel, broadly rounded behind, no hairs, the wings long and slender, base truncate, seen from below, the edge is inrolled for nearly one-half of length.

Legs rather slender, but not long, front tarsus simple, one claw; tibia with a long apical bristle, its tip extending slightly over tarsus, femora somewhat thicker, hind femora short and thick, truncate at tip, the patella at- 
tached to upper tip. Genital opening a little broader in front than long, about one and one-half its length in front of the much larger anal opening, latter wider behind than in front, which is slightly bilobed, borders of coxæ three distinct, but no evident hind border to hind coxæ.

Length $.3 \mathrm{~mm}$.

From Duke Forest, Durham, N. Carolina (Pearse), numbers 475, 433, and 238. Type M.C.Z. Arachn. 3019.

\section{Tribe Oribatini}

This tribe, which includes typical Oribata (Damæus), Belba, etc., may be divided into two sections, those with the front tibia normal (Oribata, Belba, etc.) and those in which the front tibiæ are extended over the base of the tarsus, and the tarsus shortened. In this collection are three genera which belong to this second section; they can be tabulated as below.

1. Abdomen about as broad as long, sides rounded; tectopedia not behind but beneath second trochanters; legs not slender, most joints without any swollen part; rather broad, patella narrow on short apical part, sides of tibiæ parallel; the claws borne on a stalk to tarsus Allodameus

Tibiæ narrowed at base, patellae with parallel sides; abdomen broader than long, claws not on a long stalk; tectopedia behind second trochanters just as behind first trochanters

2. Sides of abdomen nearly parallel, legs very long and slender, much longer than entire body; ventral openings united, borders of second and third coxæ nearly reaching middle of venter .....Gymnodamaus

Sides of body convex, legs scarcely as long as body; ventral openings well separated, borders of second and third coxæ not reaching half-way to middle of venter Jacotella

Jacotella gen. nov.

This is based on a small, short-legged species described as Gymnodameus quadricaudiculus ${ }^{1}$ by Jacot. Instead

1 Jour. N. Y. Ent. Soc., 45: 356, 1937. 
of the extremely long and tenuous legs of the typical Gymnodamæus the legs are scarcely longer than body, and not especially slender; the ventral apertures are well separated; there is a strong tectopedum behind first and second trochanters.

\section{Jacotella quadricaudicula Jacot}

Figs. 3, 15

One from Duke Forest, Durham, N. Car., 25 Nov. (Pearse). It was described mostly in comparison with a European species, Gymnodamaus austriacus, so I have given figures (3 and 15) of the venter and legs.

\section{Gymnodamæus Kulczynski}

Ewing, in 1917, ${ }^{2}$ erected a new genus, Heterodamæus, and included in it his Dameus magnisetosus; ${ }^{3}$ but unfortunately Ewing selected as genotype the European Damaus bicostatus Koch, a species which Kulczynski, some fifteen years before, had selected as type of Gymnodamæus. Thus Heterodamæus becomes a synonym of Gymnodomæus. Jacot ${ }^{4}$ says that Kulczynski ${ }^{5}$ assigned no type; however he is entirely wrong, for on page 43 of Kulczynski's paper is the statement "Typus Gymnodamæus bicostatus Koch."

Gymnodamæus pearsei sp. nov.

Figs. 16, 27

Dark reddish brown, border of abdomen appears black. Shape of body as in genotype, bicostatus, plainly longer than broad, not narrowed behind. Two tiny hairs near tip of head, and a longer one each side a little further back. Setæ about as long as the space separating them, swollen toward tip, but the tip sharp. Legs extremely slender and very long, as in the long-legged Oribata. The front and hind femora have rather long basal stalk, then suddenly much enlarged, then tapering to the long slender apical part, this apical part is longer in front

2 Ann. Ent. Soc. Amer., 10: 123, 1917.

3 Ibid., 129.

4 Bull. 121, B. P. Bishop Mùs., p. 18, 1934.

5 Acad. Litter. Cracoviensis, 42, Ser. B ; 43, 1902. 
femora than in the hind pair; patella one about one-third of tibia, both no wider than the slender part of femora, except in the front pair where the apex of tibia is broadened where it overhangs the base of tarsus; each joint with two long hairs in usual plan; trochanter of hind legs long and but slightly swollen, that of third legs much swollen and short, the femora with a short stalk before the swollen part, thence equally slender to the tarsi which are a little more swollen on basal part. The ventral apertures are on apical half of venter and united, the genital a little the longer; there is a dark transverse line in front of the genital opening, and from each end a faint line curves out to the margin, on each side, opposite the genital opening, is a curved dark mark; the hind borders of second and third coxæ almost reach the middle.

Length of body .5 mm., of hind leg .9 mm.

Several specimens from Duke University at Durham, North Carolina, 1 Sept., 14 Oct., 25 Nov., 10, 24 Febr., and 21 April (Pearse). Type M.C.Z. Arachn. 3012.

This species is separated from Ewing's Dameus magnisetosus, by the very much longer front tibia and the longer hind femur; magnisetosus moreover has a nearly circular venter, the legs are broader, the granulations coarser, the tarsi more slender at base.

Gymnodamæus minor sp. nov.

Figs. 28, 39

The color is yellowish; about two-thirds the size of $G$. pearsei; the body is a little more slender, and the leg's are not quite so long. The cephalothorax is similar but the hair at each side of tip of head is more clavate, the seta is similar, the tip long, fusiform, and scabrous. The first legs are not quite as long as the body, the femora bulbous close to base, before middle faintly sinuous, patella nearly as long as bulb of femur, the tibia becoming broader to the swollen tip, the tarsus attached as in $G$. pearsei, the tarsus is proportionally more swollen than in pearsei, hairs similar, but the one at tip of tibia apparently not as long as in pearsei. The fourth legs about equal to length of body; the femora are bulbous 
quite close to base, so that the stalk of femur is extremely short (much longer in pearsei). The tarsus is fusiform, quite hairy toward tip. On the venter the apertures are separated slightly more than in pearsei, but connected by a dark, chitinous area; the outlines of coxæ are not visible, only at margin is a dark circle at base of leg three and four. Coxæ one and two are separated by an oblique bar, not reaching one-half way to middle, at tip of abdomen are three hairs each side, all short, but one is much longer than others, and curved almost in a circle.

Length $.35 \mathrm{~mm}$.

From Duke Forest, Durham, North Carolina, in January, March and April, numbers 238, and 505. Type M.C.Z. Arachn. 3013.

Readily separated by the very short stalk to the hind femora, as well as size, color, apical hairs of abdomen, etc.; also separated from Damcus magnisetosus Ewing, by the more slender and less coarsely granulose legs; the front tibia is similar in length to that species, but the tarsus is narrow at base and swollen in middle; the abdomen of magnisetosus is much broader, nearly circular, the hind femur of Ewing's species has the hind femur swollen in middle with a short stalk at each end.

Allodamæus gen. nov.

In appearance this resembles a Belba, but the second tectopedia are present, but bent under the second trochanters and so not noticeable from above. The abdomen is as broad as long, broadly rounded, the ventral openings are separated by a short space. The legs are of moderate length, much as in Belba; in the front legs the tip of the tibia extends over the base of tarsus much as in Gymnodamæus, but more broadly. The tarsus, instead of gradually tapering to a fine point, is abruptly narrowed some distance before tip, thus the claws are attached to a long, slender stalk that has the appearance of a separate joint. The legs, of moderate length, are not especially slender, nor scarcely swollen on any joints, except the trochanter (like Ewing's figure of Damaus magnisetosus). However in essential characters it belongs in the Oribatini, near to Gymnodamæus. 
Type is Allodamaus ewingi $\mathrm{n}$. sp.

The nymph of this or some allied species has two long, curved setæ at tip of abdomen (figure 6 ).

Allodamæus ewingi sp. nov.

Reddish brown to dull yellowish brown; there is a pulverulence over the legs which has the appearance of equally short erect hairs on each side of each joint; it is also over the front of head. The fine hairs on the legs are, at first, scarcely noticeable, a much stouter hair arises from near tip of third trochanter. The tectopedium behind first trochanter has a tooth on outer side. The ventral openings are but little separated, the anal slightly the longer, the genital almost its length from the transverse bar at base of abdomen, the anal opening is nearly one-half its length from the end of venter. Above on the cephalothorax at each basal corner is the base of the seta, but no seta is visible unless it is very short and capitate; a little in front arises the superior bristle, which near tip is somewhat thickened.

The front legs are nearly as long as width of the abdomen, the hind legs as long as the entire body. The base of the patella and tibia is suddenly broadened, like a basal collar to the joint, the patella is much narrowed beyond the collar, but the tibia continues broad to the attachment of the tarsus, and in front legs the upper tip of tibia is extended in a point over fully one-half of the thick basal part of tarsus, the tip of the tibial projection has a very long hair.

Length $.7 \mathrm{~mm}$.

From the forest of Duke Univ., Durham, North Carolina, 1 Sept. (Pearse). Type M.C.Z. Arachn. 3014.

Oribata carolinensis sp. nov.

Figs. 41, 42

Cephalothorax plainly narrowed a little in front of first legs, a curved anterior bristle each side near tip, and one on each side margin near tip, seta fully equal to length of cephalothorax, whip-lash type, the lash very fine and delicate. Abdomen nearly as broad as long, 
with a row of curved bristles toward each side, six shorter incurved bristles at tip; ventral apertures touch, the genital nearly circular, the anal nearly as long as the genital, but only about two-thirds as broad.

Legs slender, all tarsi long; fourth legs much longer than body, the first legs almost as long as body, the stalk of femur curved and nearly as long as the swollen part, the patella about one-half the tibia, latter (from side) much swollen, fusiform, tarsus with bulb-like swelling near base, the tapering part nearly equal to tibia plus patella. Hind legs with trochanter nearly one-half of femur, latter with stalk nearly one-half of length, swelling fusiform; tibia a little longer than femur, very slender, except a triangular swelling near tip, tarsus little, if any, longer than tarsus of first legs, a swelling near base, tapering to tip. Most of the hairs on legs are slightly curved and minutely pectinate. Second legs much like first, but shorter, third legs much like fourth, but much shorter, the tibia slightly thickened toward tip.

This species is near to O. longiseta Bks., but in that species the hind tibia is not nearly as long as tarsus, and latter not so bulbous near base, the hind tarsus plainly longer than front tarsus, the hairs on legs not so plainly pectinate, on abdomen the hairs are short and straight, and on venter the genital aperture is plainly separated from the anal, and not so nearly circular.

Length $.55 \mathrm{~mm}$., hind leg $.8 \mathrm{~mm}$.

From Duke Forest, Durham, North Carolina, MarchApril (Pearse coll.). Type M.C.Z. Arachn. 3010.

Oribata diversipes sp. nov.

Figs. 31, 33

Cephalothorax much narrowed in front of first legs, the sides there scarcely curved, just behind head the cephalothorax is much broadened, then narrowed, and then curving outward for second legs, then much narrowed to base; there is a stout, blunt, curved tectopedium behind both first and second legs, stigma about twice its diameter from margin, the seta long, with a fine whip-lash tip; each side of head near tip are two rather long, curved hairs. 
Abdomen globose, four short curved hairs at tip, probably some hairs on dorsum, but the dorsum is cracked and rubbed so I see but two bases for hairs. Venter with openings a little separated, but connected by a narrow median ridge, the genital aperture nearly circular the anal more pear-shaped, behind nearly as broad as the genital, but much narrowed in front, broadly separated from the hind border of abdomen.

Legs long, all tarsi long and fine; first legs equal to length of body, femora, tibiæ and base of tarsi swollen about as much as in most species; the second legs a little shorter, the third nearly as long as body, both with distinct swellings though smaller than on first leg's, hind legs very much longer than body, fully one and one-half as long, the tibia plus tarsus equal to body, the swellings are very like angustipes and that on femur is longer than usual. Most of the hairs on legs are curved, one on tarsus is very long and nearly parallel to tarsus, on the tip of hind tibia is a long, diverging hair with a fine curved tip, much like those of grossmanni, and some others. On the second trochanter is a long hair curving forward, a much shorter one on first trochanter.

Length .5 mm.

One from Duke Forest, Durham, N. Car., March-April (Pearse). Type M.C.Z. Arachn. 3009.

Belba inæquipes sp. nov.

Figs. 32, 43

Body and legs pale yellowish. Cephalothorax more than one-half the length of abdomen, latter rather short and broadly rounded behind; no tectopedia behind first legs, a prominent spike-like one behind second legs, also in front and behind base of third legs is a small projection. The seta is long and with a whip-lash tip as in $B$. florida. The abdomen is strongly convex, with a row of bristles on each side, and six shorter ones on hind margin near tip; the venter is nearly circular, the openings are subequal and rather close together. The legs show definite bulbous swellings on femur, tibia and tarsus, all tarsi very slender and long. The front femora 
have the swollen part but little longer than the curved stalk; the tibia is strongly swollen, with a fairly long stalk, the tarsus also has a distinct thin stalk before the bulb, the part beyond long and tapering. The hind legs are about as long as body, the trochanter very long, nearly or quite as long as the femur, latter swollen in middle, tapering each way to the short stalk, the tibia has a less swollen part at tip, with a stalk more than twice as long, the tarsus has a short stalk before the bulb, a long and very slender part beyond. The third legs have the very long tarsus, but the tibia is only about one-half of tarsus. The legs are not especially hairy, the long hair of front tibia much before tip and scarcely longer than the joint.

Length of body .4 mm.

Two specimens from Duke Forest, North Carolina (Pearse), \#238, January, and March-April. Type M.C.Z. Arachn. 3011.

The mite, at first, with very long hind legs resembles Oribata angustipes, the front leg's, however, are very different, and in the hind legs the femur is much shorter than in angustipes.

\section{Oppiella apicalis Jacot}

Figs. 14, 17

The specimens from Duke Forest have the tip of cephalothorax more acute than in the typical form. The seta shows a head distinctly longer than in Jacot's fig. 4, with a few short hairs near tip, possibly others toward base. Probably it will be best to consider the subspecies of $O$. corrugata which Jacot describes, apicalis, squarrosa, the form mentioned by Jacot from Great Falls, Va., and the one figured here as only some of the forms of a variable species, Oppiella apicalis (which has precedence).

\section{Autogneta amica Jacot}

Figs. 19, 21

One specimen from Duke Forest, Durham, N. Car.

The legs are short and slender; the base of the tarsus is sunk into the concave apex of the tibia in all legs, but 
most strongly in the front legs where the upper end of tibia extends nearly over the basal half of tarsus and is tipped by a long hair; the slender stalk of the tibia is curved in all legs; all of the tarsi are very hairy on apical half, and the claw is very long; all patellæ are very short, and the tip of femur is lobed on each side.

The cephalothorax is narrowed at base and widest at base of the first tectopedia. A little in front of each basal corner is a large, rounded scar, from its anterior inner corner arises a ridge which curves inward and then extends forward parallel to its fellow for fully three-fourths of length of cephalothorax. From the anterior outer corner of each scar arises the long seta, tipped by an elongate swelling; superior bristles apparently lacking, but the round insertion is seen opposite the turn of the ridge.

The abdomen, not twice the length of the cephalothorax, is broadest behind the middle. On the venter is a strong division and constriction between the cephalothorax and the abdomen, there is but little indication of coxal limits, but the second (apparently) is a broad plate separated from its fellow by a somewhat triangular outline, a faint curved line crosses just in front of genital opening and slopes backward to indicate hind border of the fourth coxa.

The genital aperture is broader in front than behind, the anal opening much larger, and fully one and one-half its length from the genital opening. Dolicheremcus rubripes Jacot, Florida Entom., 1938, is very similar in general appearance to this species, the body is more slender.

Carabodoides retracta sp. nov.

Figs. 9, 29

Cephalothorax fully as broad at base as long, abdomen about one and a third times as long as broad, broadly rounded behind. Seta spatulate, the broadened tip flat, with rounded outer tip. The cephalothorax above has irregular low, narrow ridges, one starts from close to the stigma, extending obliquely forward and inward, then turns to run parallel to outer margin of cephalothorax. 
The legs are short and stout the femora especially thick. In the front leg's the tibia is cup-shaped, its tip nearly as broad as its length, this tip is concave and the basal part of tarsus is retracted within it, the tip of tibia above has a long hair. The short tarsus is suddenly narrowed from above and here there are a few hairs. In the hind legs the femora are broad, shouldered, subtriangular, the hind tarsus about equal to tibia, its tip scarcely reaching tip of abdomen. The front leg's are hardly as long as width of abdomen.

The genital aperture almost touches the anal, is broader in front than the anal, but behind is a little more narrow than anal, latter is fully as long as genital, but quite narrow in front and fully twice as broad behind.

Length .55 to $.6 \mathrm{~mm}$.

From Duke Forest, N. Carolina, numbers 475, 238. The front tibia is more modified than in apicalis or sacchariomycetoides. Type M.C.Z. Arachn. 3018.

\section{Eremobelba gracilior Berlese(?)}

Figs. 10, 23

Related to $E$. flagellaris, smaller, abdomen more elongate. Cephalothorax with two fine linear carinæ in middle, at first parallel, then each turns outward, stigma close to base, hardly its diameter from outer margin; seta long, slender, ending in a fine whip-lash. Above the base of leg one is a shorter carina, reaching forward of lateral margin.

Abdomen nearly one and one-third as long as broad; the anterior lateral margin appears heavier (as in Berlese's figure) with hairs about as in figure but not all distinct in this specimen; four on hind margin, and a submarginal row, and an apparent oblique row.

On the venter the triple U-suture across base of the camerostome and ending at tectopedial spines is very distinct. The genital aperture is a little longer than broad, hardly one-third its length in front of the larger anal aperture, which is broader behind, and separated from hind margin almost as far as from genital aperture.

The legs are finely granular and more slender than in 
flagellaris, especially the tarsi beyond the swelling; the bulb at tip of front tibia is plainly a little broader than long, and almost touches the swelling on base of tarsus; the hind femora are plainly pedicellate, and all patellæ are quite long; the tarsi are very hairy.

Length $.4 \mathrm{~mm}$.

From the Duke Univ. Forest, Durham, N. Car., numbers $238,487$.

From the fourteen words of description of Berlese it is hardly possible to recognize this species, but the figure agrees in several particulars. However, the most characteristic points in the legs are not given, since the legs were not figured. His figure shows a long simple seta, but it is possible that the whip-lash tip was lost.

\section{Zetorchestes equestris Berl.}

Fig. 26

One specimen from Duke Forest; it is apparently rare; I had never seen it, and none in the Jacot collection.

The body is broadly rounded except in front, where it comes to a point. The first three coxæ are close together in front, the hind coxæ situated much further back. Hind legs much longer and stouter than the others, with a spine at tip of tibia, and two on outer edge of tarsus. Ventral openings connected by borders, the anal much the larger, broadest toward rear, genital not nearly so long and about two-thirds as broad, more than its length behind the third coxæ. Tarsi of front legs rather slender, nearly twice as long as tibia. Above the cephalothorax has a lateral dark lamella on outer side, two-thirds of length of cephalothorax. The seta is paddle-shaped, a slender stalk and a large flat ovoid tip, somewhat lined and with numerous minute points.

Length .4 mm.

\section{Xenillus occultus sp. nov. Figs. 5, 7}

Dull brownish rufous; surface very minutely roughened; body about two-thirds as broad as long, broadly rounded behind, and there with a few erect hairs, each 
with the tip slightly enlarged, four each side projecting beyond abdomen, and three or four others each side toward tip. Cephalothorax with two elongate, incurved plates (fig. 7), broadest before tip where they almost meet, tip broad, concave, the outer point more prominent, each plate bears a long, roughened, stout bristle from middle of the tip; tip of head with a short, curved bristle each side; at base of the cephalothorax a fairly broad transverse area is delimited and from each upper corner arises the subbasal bristle, enlarged at tip; each seta is nearly as long as this bristle, clavate at tip; each first tectopedium is enlarged and projects laterally, with a sharp outer point anteriorly.

Legs slender, fairly short, joints but little swollen, three equal claws ; first legs about length of body, patella nearly one-half of tibia, but few hairs, a long one at tip of tibia above, one, nearly as long, from tarsus before middle, elsewhere but few short hairs; second and third legs hardly width of body; the fourth legs scarcely reach the tip of body.

On the under side are three parallel cross-bars; one at base of first coxæ, one at base of second coxæ, the third, more curved passing behind third coxæ and reaching nearly to fourth coxæ; in the middle this cross-bar is confluent with the curved bar from fourth coxæ, which touches almost the half of genital aperture; the latter is a little longer than broad, scarcely truncate behind.

The anal aperture is twice as long as the genital and situate about one and one-fourth its length behind the genital aperture in the female, fully one and one-half its length behind in the male.

Length of female $.7 \mathrm{~mm}$., of male $.55 \mathrm{~mm}$.

Two specimens from the Duke Forest, North Carolina. Type M.C.Z. Arachn. 3024.

Eremæus politus sp. nov.

Figs. 20, 22

Pale yellowish. Cephalothorax plainly longer than broad, narowed in front of first legs, in middle with two slightly curved and parallel carinæ; first legs far in front 
of second, the stigma more than its width from side, behind is a transverse ridge, narrow through the middle, widened behind and beyond stigma, setæ longer than distance between their bases, the head long, and slender, scabrous. A tectopedium behind coxæ one, and also two, the latter rather complicated.

Abdomen fully one and one-half times as long as broad, sides but slightly convex; on each side of the basal part is a short strip of granules. The genital opening plainly longer than broad, about its length in front of the larger anal opening, latter narrow and faintly bilobed in front, more than twice as broad behind. The fourth pair of legs considerably behind the third; the side of the venter between these two pairs is convex, the hind coxæ occupying most of the area, and strongly curved behind. Legs short and stout, with but few fine hairs, almost wholly on tarsi, three claws; all femora thickened, front ones strongly so, and with a ridge or lamella below, tibia short, little if any longer than tarsus, front tarsus from side slightly swollen; hind legs reach nearly to tip of abdomen.

Length of body .4 mm.

From Duke Forest, N. Car., numbers 475, 433, 514. Type M.C.Z. Arachn. 3017.

\section{Epilohmannia elongata sp. nov.}

Fig. 40

Pale yellowish brown, legs almost colorless. Body slender as usual, somewhat broadened in middle of abdomen; above without evident hairs; seta short, with clavate tip. The head in front is almost in a point; tip of abdomen broadly rounded. Front legs a little heavier than the others, tarsi quite thick and with a number of rather short hairs, one claw; tibia very broad, rounded on each side, a long hair a little before tip; the third joint before tip (patella?) longer than other joints, narrow on base, but much broadened before tip, scarcely as broad as tibia, second and third legs shorter, about as long as the greatest width of abdomen, the second, third, and fourth joints narrowed on base; fourth leg much longer, reaching to tip of abdomen; first visible joint (trochanter?) very 
long and extended on outer side at tip over base of next joint, next three joints subequal, narrowed on base, tarsus slender and longer than the preceding joint, all tarsi with a few hairs, the claw very large. Hind coxæ much broadened toward tip, together showing a deep median excavation behind.

The genital opening is situate the length of its base from the base of this excavation; it is roundly broadened behind to a width equal to its length, and here there is a line reaching almost across venter, and crossed by a sloping longitudinal line extending back to middle of anal opening. Anal opening not quite half its width behind the genital, its sides rounded, and slightly narrowed behind, its length plainly a little less than the genital opening. Surface of venter around genital opening shows numerous well-separated granules, and also many down the middle of genital covers, the margins free of them. The second coxæ are very broad, the third much narrower, especially on base; the first coxæ are triangular, the pointed base not reaching middle.

Length .35 mm.

One from the Duke Univ. Forest, Durham, N. Car., 21 Oct. (Pearse). Type M.C.Z. Arachn. 3016.

\section{Lohmannia brevipes sp. nov.}

Figs. 34, 36

Body a little more than twice as long as broad, sides of abdomen nearly parallel, tip broadly rounded, tip of head rounded, a fine hair each side; the superior bristles are barbed, and situate close to base of seta, latter is a hyaline scale truncate at tip. On each lateral edge of abdomen are six bristles or scale-like hairs, the first four are barbed or roughened bristles, the first bristle near base of abdomen, second about opposite base of genital opening, two others further behind, and nearer together, beyond are two broadened, or scale-like hairs with barbed edges, the last close to tip of abdomen; above on abdomen, not far from margin, is a row of four shorter, also roughened bristles, the first and second close to the first and second marginal bristles. The genital aperture much 
more narrow than the anal, and a little shorter, its sides nearly parallel, each cover with about nine hairs as in figure; the anal opening connected to the genital, the sides are curved outward, the covers not occupying available space, and each cover with a row of four barbed bristles.

The legs are very short and stout, the front pairs heavier than others, the femora are narrowed at base, and the tibiæ are concave on inner edge, there are some hairs chiefly on tarsus, some on the hind legs are barbed hairs, and also some on outer side of femora one and two are broadened scale-like and roughened; the single claw is very long, the curve mostly near tip; a long hair at tip of tibiæ.

Length .28 mm.

Several specimens from Duke Univ. Forest, Durham, N. Car., 21 Oct., 4, 25, Nov. (Pearse). Type M.C.Z. Arachn. 3015.

\section{LABIDOSTOMMATID A \\ Labidostomma mamillatus Say (Erythræus) \\ Figs. 4, 12, 18}

Say's species has not been recognized previously; Jacot suspected it might belong to Labidostomma, but none had been taken since Say's time. In 1930 I took one in the Smoky Mts. of North Carolina, and Prof. Pearse sends several specimens taken at Duke Forest.

The mandibles above are mostly covered with an arrangement of imbricated rounded scales (castanulate); the jaws are smooth, and slightly outcurved at tip. On the swollen part of mandible not far from base of the jaws is a sloping tubercle, tipped by a long, fine bristle. Each side of the front margin of the body ends in a sharp point, also tipped by a bristle.

A short distance behind the front is a transverse, nearly parallel ridge, most prominent on the sides, between this and the front margin the surface is sculptured as on the mandibles and also in a median raised region behind the ridge, elsewhere the sculpturing is less perfect, tending to be reticulate or granulate. Each side of the median raised area is a fairly prominent clear spot with a hair, possibly corresponding to stigma and seta; a few smaller 
hairs and bases on front part of body. The side before middle is somewhat swollen, and here are the two "eye spots," facing laterally. The hind one is very large, the one in front much smaller; just in front of the small one arises a long, back-ward directed bristle; two very short hairs at tip of body.

On the venter the coxæ meet in the middle and beyond are six joints, the first and third are quite short (probably trochanter and patella), beyond are two long and the short terminal joint, probably tibia, protarsus and tarsus. The front tarsus ends in two nearly equal claws. The other legs do not have a short patella, the fourth joint from tip being longer than the one beyond it, and the last joint (tarsus) much longer than the penultimate; all legs have fine short hairs, most abundant on the tarsi. The tarsi of the second, third, and fourth pairs end in three claws, the median claw not as much curved as the laterals.

In the female the ventral openings are united in one, which is divided by a transverse line at posterior third, near sides the line curves forward. In the male the two openings are slightly separated, the genital much the larger.

\section{Explanation of Plates}

Plate 5

Fig. 1. First leg of Erythrous carolinus, and hairs from body.

Fig. 2. Oribatella carolina, cephalothorax and base of abdomen from above.

Fig. 3. Jacotella quadricaudicula, venter.

Fig. 4. Labidostomma mamillatus, "eyes", from above.

Fig. 5. Xenillus occultus, venter.

Fig. 6. Allodamaus ewingi, tip of abdomen of nymph.

Fig. 7. Xenillus occultus, cephalothorax.

Fig. 8. Oribatella carolina, venter.

Fig. 9. Carabodoides retracta, cephalothorax.

Fig. 10. Eremobelba gracilior, cephalothorax, and venter.

Fig. 11. Erythrous carolinus, corner of cephalothorax, and palpus. 


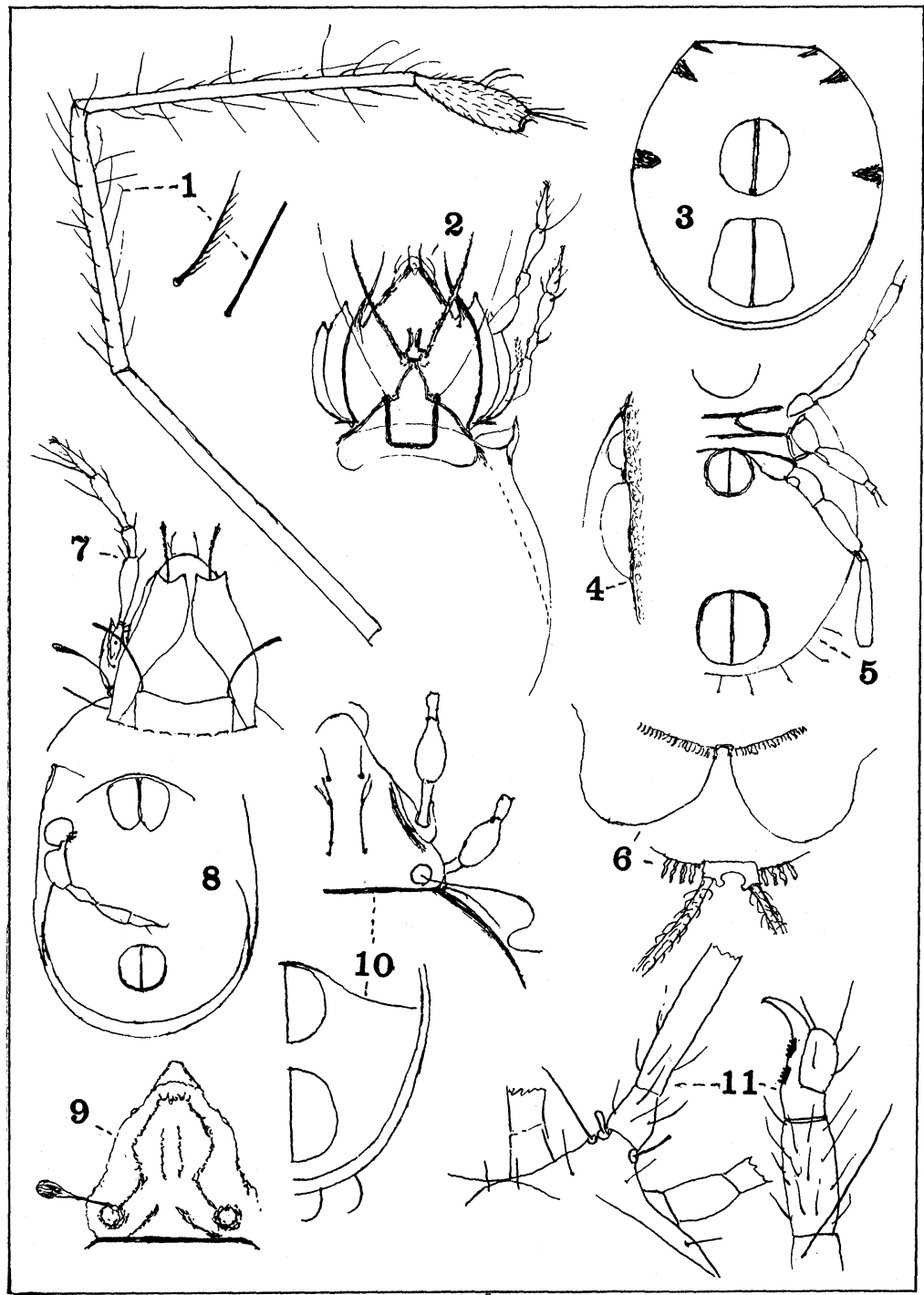

BANKS-ACARINA 
Fig. 12. Labidostomma mamillatus, side of cephalothorax; first leg, palpus, ventral apertures of male, and sculpture of mandible.

Fig. 13. Allodamceus ewingi, first and second legs.

Fig. 14. Oppiella apicalis, side of cephalothorax, and venter.

Fig. 15. Jacotella quadricaudicula, seta, and apical part of first and fourth legs.

Fig. 16. Gymnodamceus pearsei, under side.

Fig. 17. Oppiella apicalis, cephalothorax below.

Fig. 18. Labididostomma mamillatus, ventral aperture of female.

Fig. 19. Autogneta amica, part of cephalothorax, and front tarsus. 


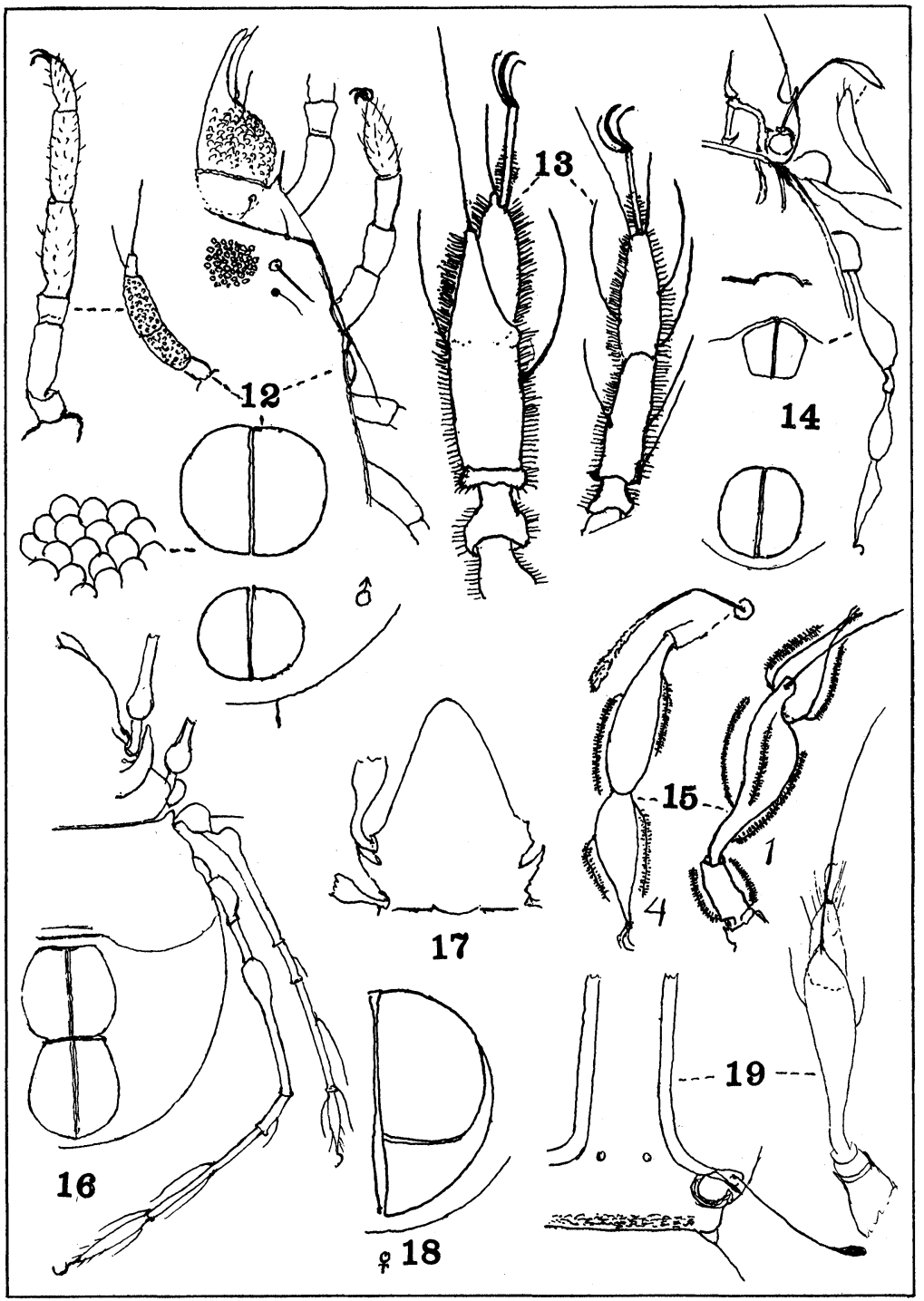

BANKS-ACARINA 
Fig. 20. Eremaus politus, cephalothorax, first leg, and claw.

Fig. 21. Autogncta amica, venter.

Fig. 22. Eremcus politus, venter, and second leg.

Fig. 23. Eremobelba gracilior, cephalothorax from below, and fourth leg.

Fig. 24. Alloribates singularis, cephalothorax, wing from side, third and fourth legs, and first tibia and tarsus.

Fig. 25. Alloribates singularis, venter, and fourth leg. 


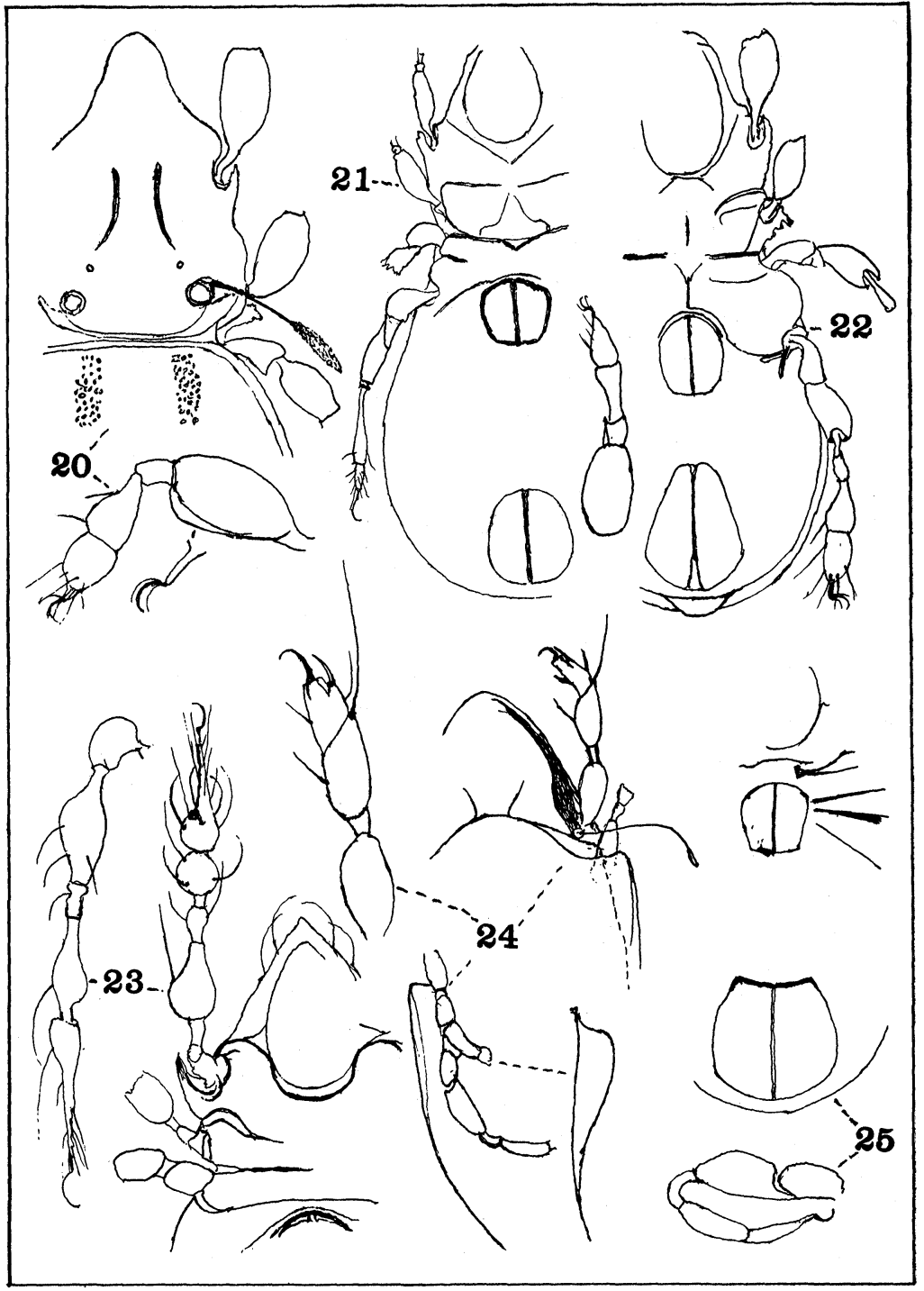

BANKS-ACARINA 


\section{Plate 8}

Fig. 26. Zatorchestes equestris, venter, edge of cephalothorax, seta, and first leg.

Fig. 27. Gymnodamoeus pearsei, first tibia and tarsus, seta, tip of cephalothorax, and attachment of first leg.

Fig. 28. Gymnodamaus minor, first leg, showing tibia beneath, tibia and tarsus of first leg, showing tibia from side, fourth leg.

Fig. 29. Carabodoides retracta, venter, seta, and first leg and edge of cephalothorax.

Fig. 30. Erythrceus exilipes, palpus from two views.

Fig. 31. Oribata diversipes, cephalothorax, and venter. 


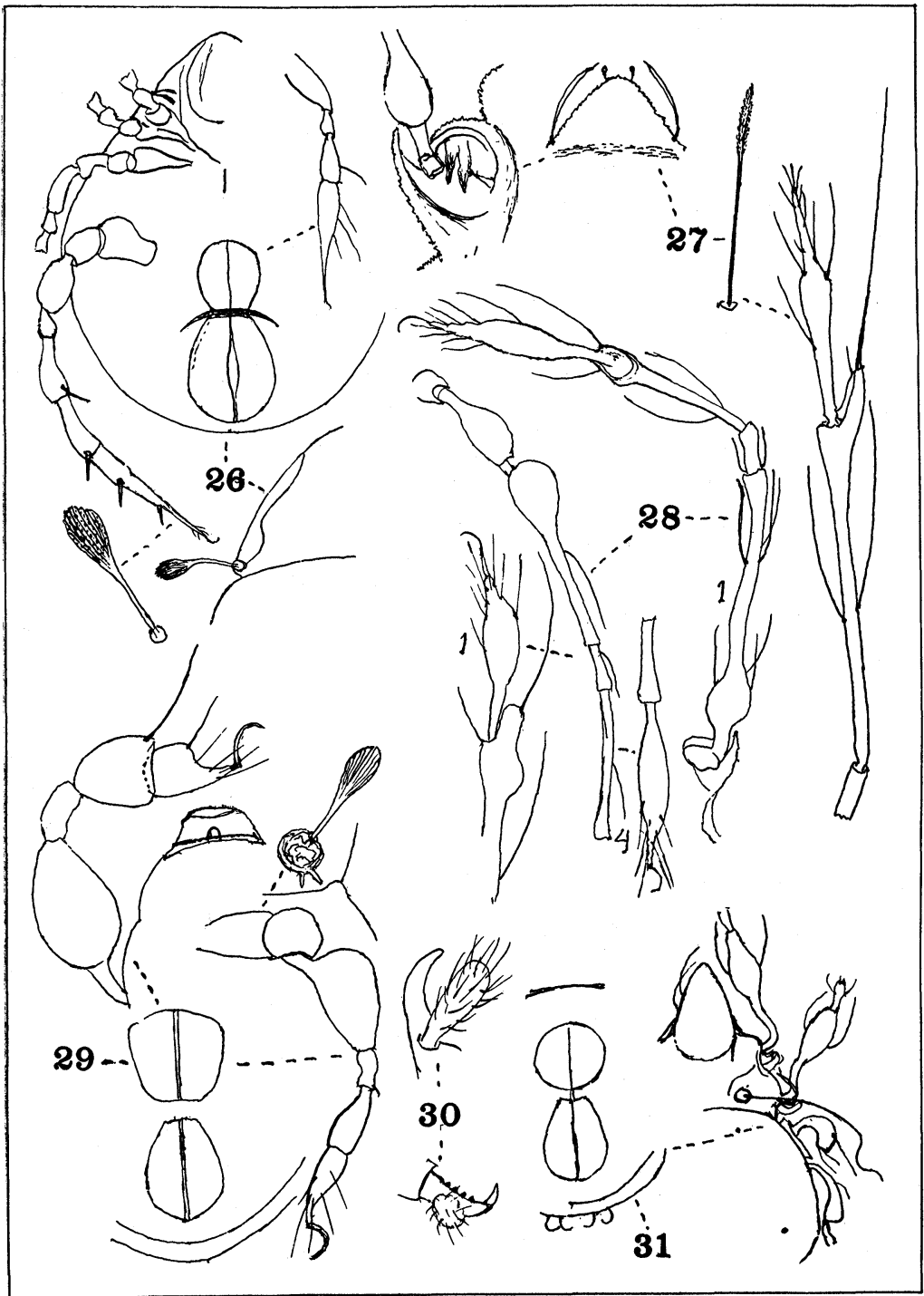

BANKS-ACARINA 
Plate 9

Fig. 32. Belba inoequipes, first and fourth legs.

Fig. 33. Oribata diversipes, first, third, and fourth legs.

Fig. 34. Lohmannia brevipes, fourth leg.

Fig. 35. Erythrous exilipes, tibia and tarsus of first and fourth legs, eyes.

Fig. 36. Lohmannia brevipes, venter, and seta.

Fig. 37. Minunthozetes angusta, venter, tibia and tarsus of first leg.

Fig. 38. Minunthozetes angusta, dorsum. 


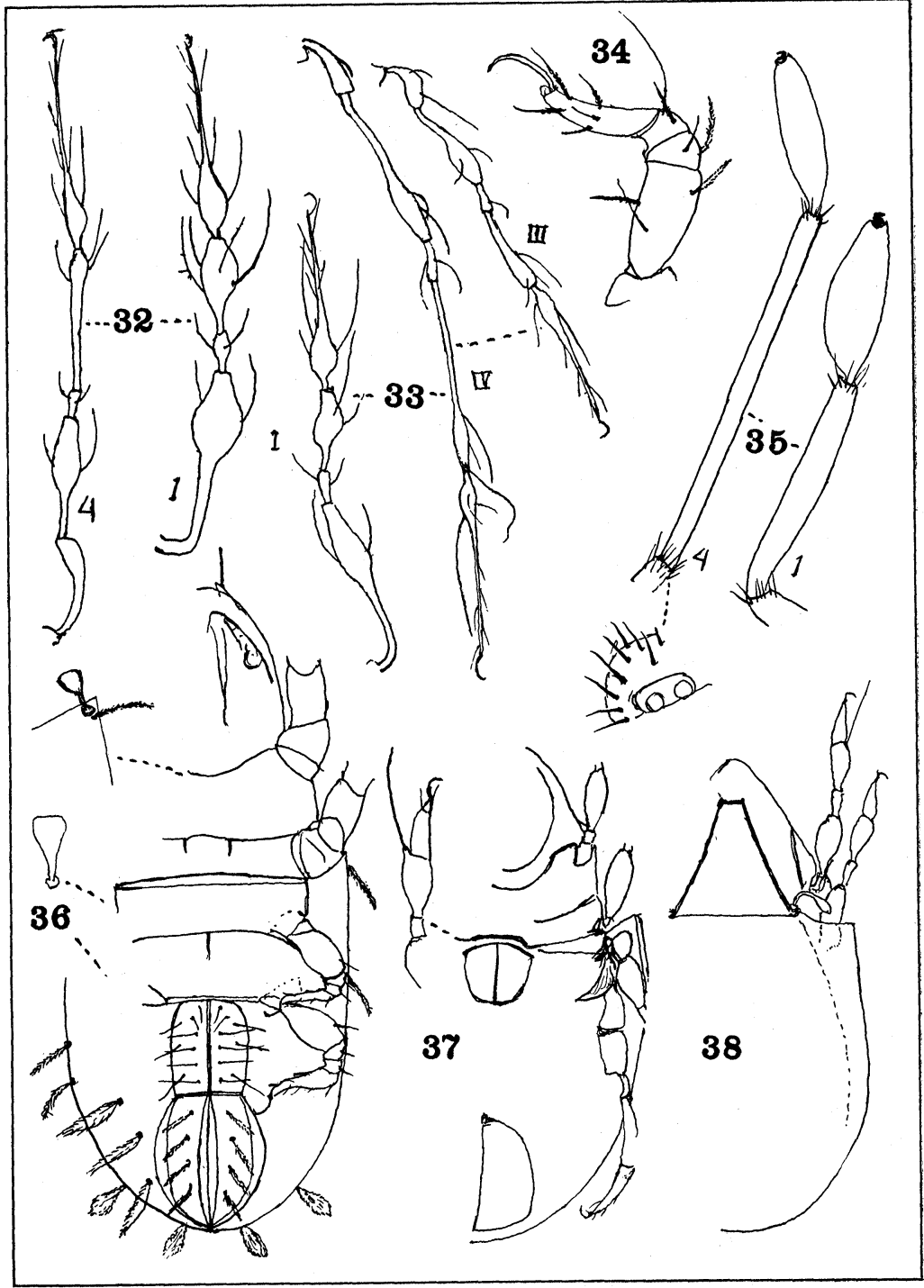

BANKS-ACARINA 
Fig. 39. Gymnodamaus minor, side of cephalothorax, seta, and ventral Fig. 40. Epilohmannia elongata, under side.

Fig. 41. Oribata carolinensis, first, and fourth legs.

Fig. 42. Oribata carolinensis, above.

Fig. 43. Belba incequipes, side of cephalothorax, seta and tip of abdomen.

Fig. 44. Allodameus ewingi, side of eephalothorax. 


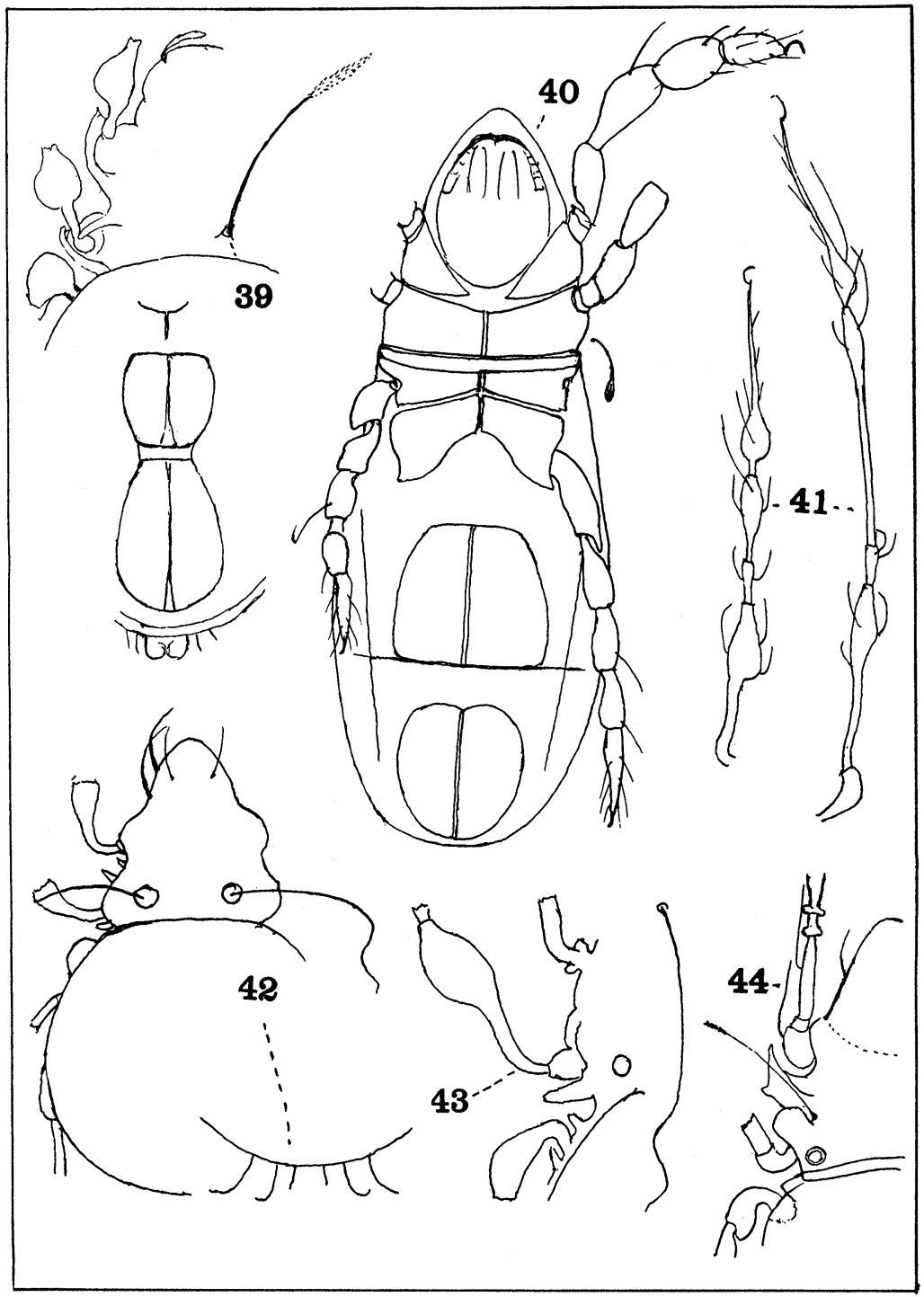

BANKS-ACARINA 

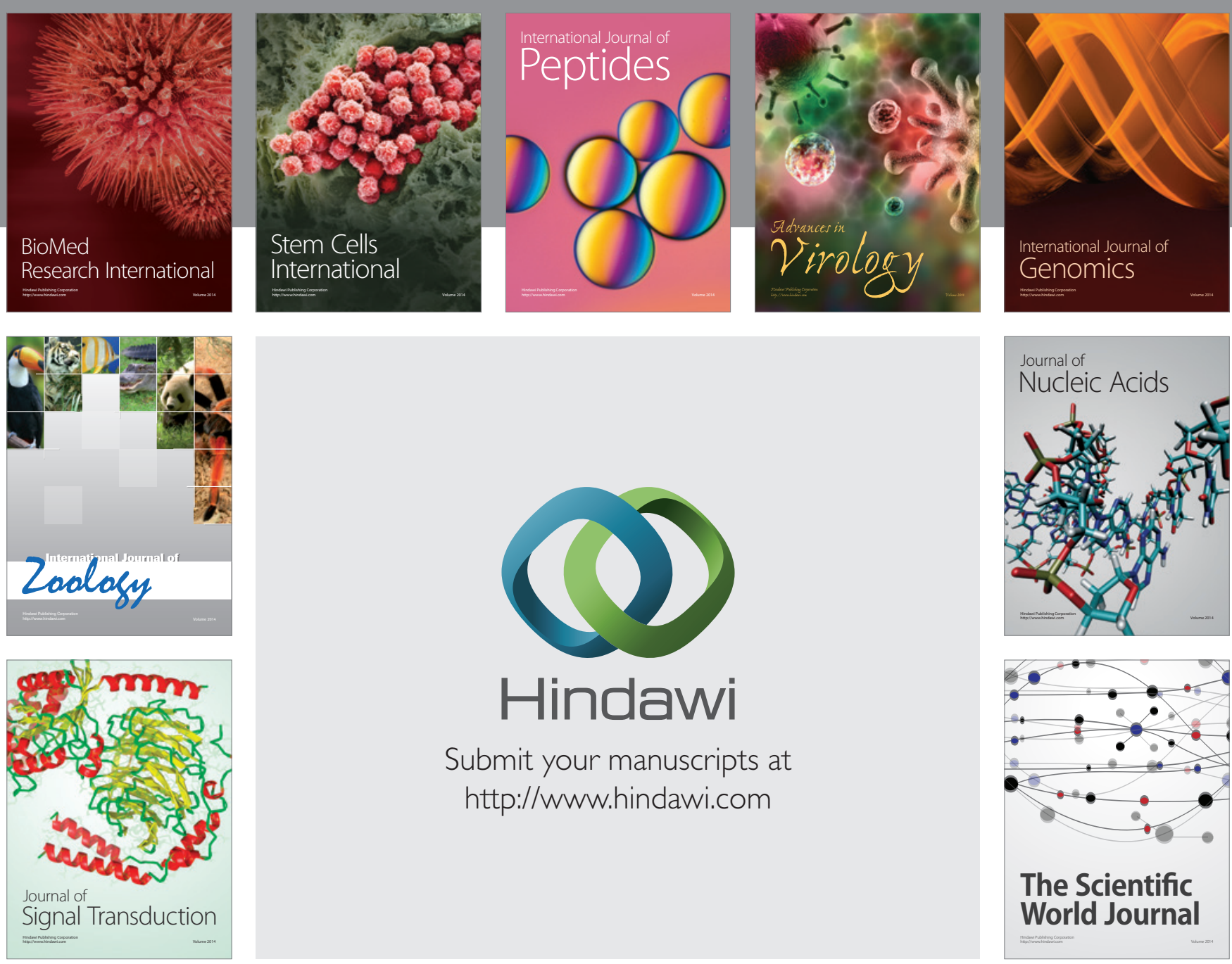

Submit your manuscripts at

http://www.hindawi.com
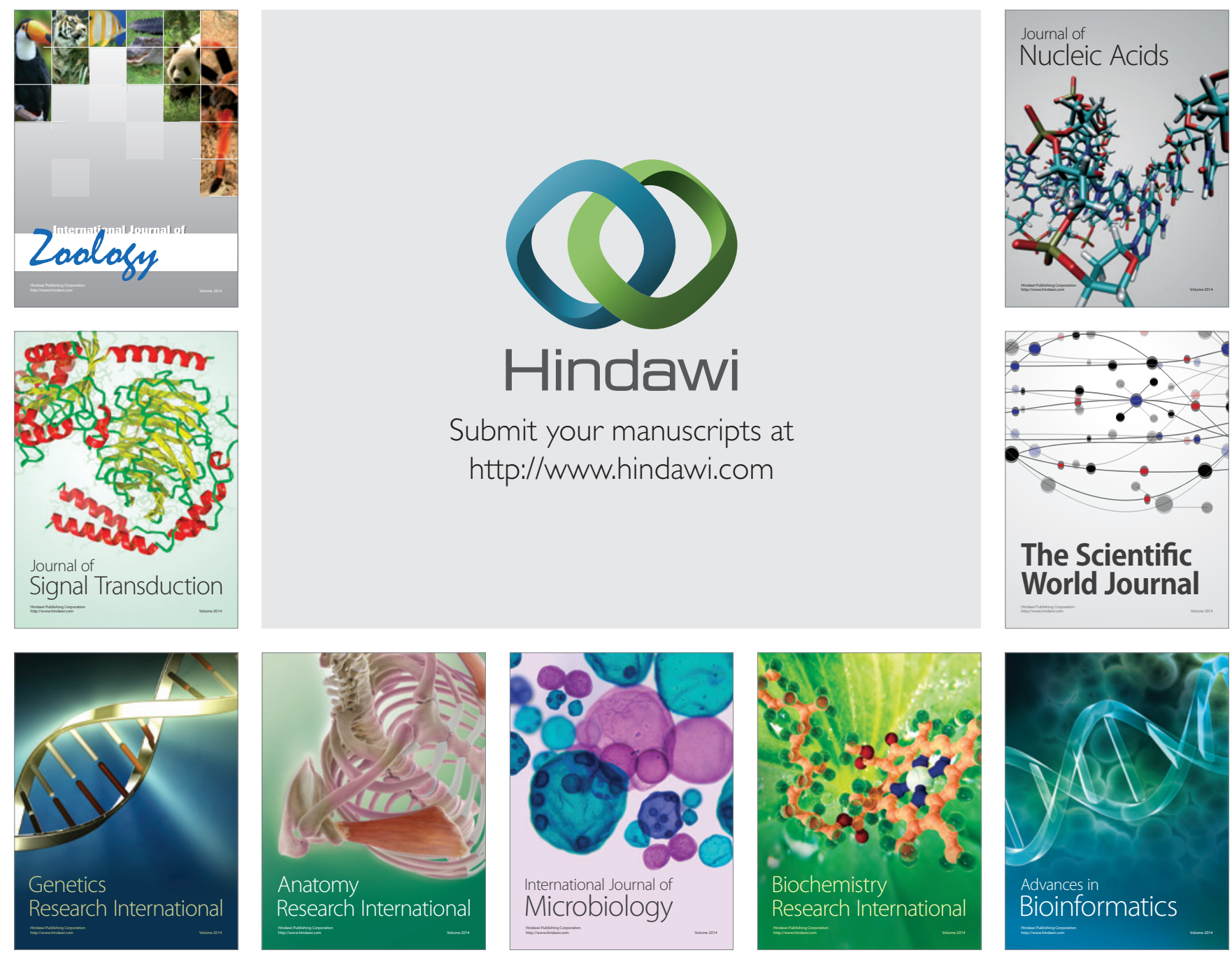

The Scientific World Journal
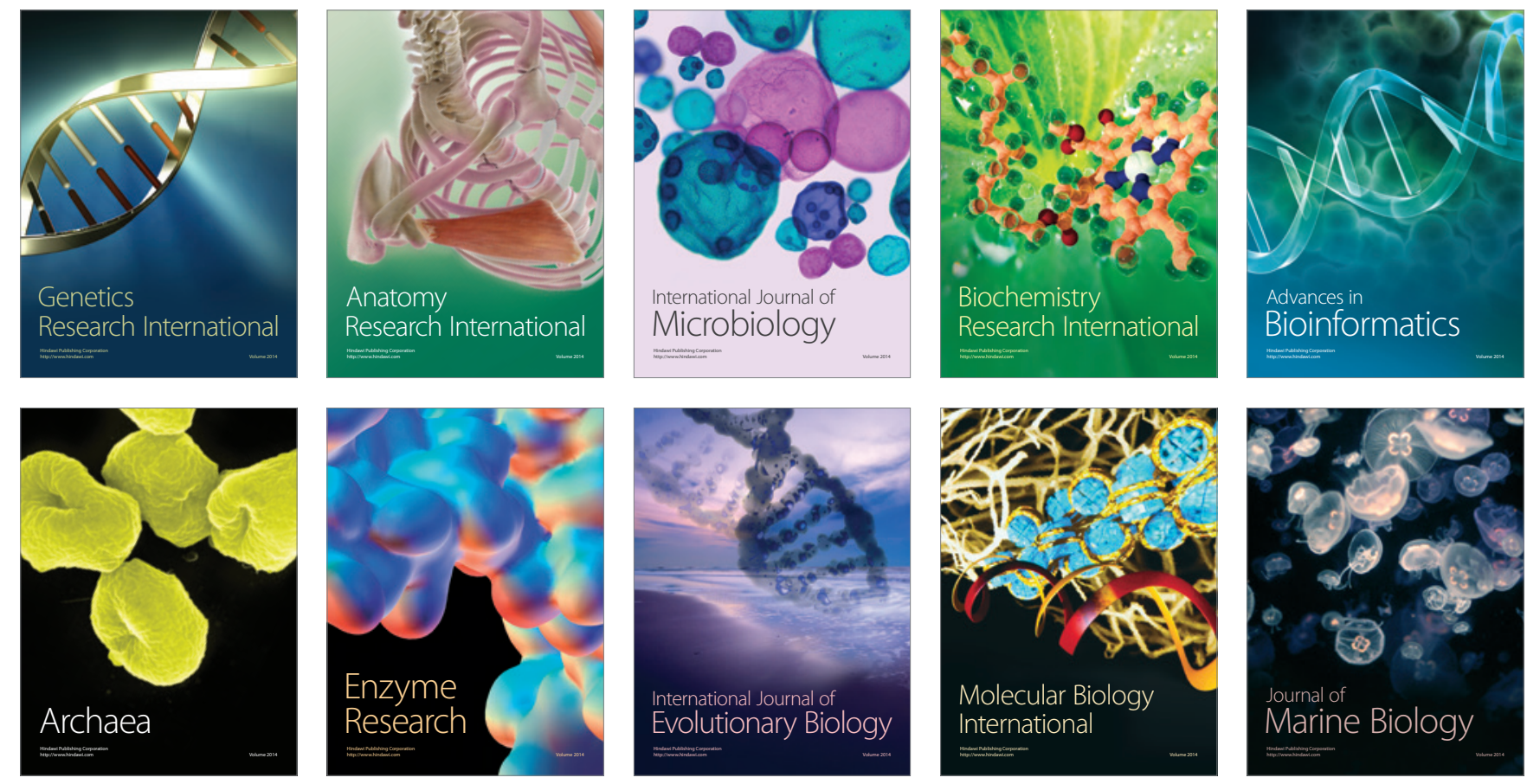